\title{
STRATEGI MENINGKATKAN DAYA SAING INDUSTRI KREATIF INDONESIA: STUDI KASUS PENGEMBANGAN KLASTER INDUSTRI ALAS KAKI KECAMATAN TAMANSARI, BOGOR
}

\author{
Gema Setya Anggara Putra
}

PPM School of Management Jakarta

\author{
Noveri Maulana \\ PPM School of Management Jakarta \\ noverippm@gmail.com
}

Diterima 17 April 2018

Disetujui 12 Desember 2018

\begin{abstract}
Peningkatan daya saing industri kreatif Indonesia menjadi perbincangan sengit seiring pemberlakuan Masyarakat Ekonomi ASEAN (MEA) di penghujung tahun 2105 silam. Presiden Jokowi melalui Badan Ekonomi Kreatif (BEKRAF) selalu berupaya untuk mempercepat peningkatan daya saing industri kreatif sebagai kekuatan ekonomi baru di Indonesia. Namun, belum banyak industri kreatif yang mampu berkembang dan memiliki daya saing tinggi ketika berada di tengah pasar industri global. Penelitian ini diharapkan mampu menjadi salah satu alternatif solusi untuk menjawab permasalahan itu. Melalui kajian mendalam atas industri alas kaki di Kecamatan Tamansari, Bogor, penelitian ini diharapkan mampu merancang sebuah model strategi daya saing bagi industri kreatif tanah air. Menggunakan model porter diamond analysis, penelitian ini akan menyusun rancangan strategi bagi klaster industri alas kaki Tamansari serta mengkaji faktor peluang dan ancaman dalam mengembangkan industri kreatif. Penelitian kualitatif ini menggunakan pendekatan studi kasus dan teknik perolehan data menggunakan wawancara, observasi, FGD, dan analisis dokumen. Setelah data dianalisis melalui coding dan kategorisasi, maka dapat ditarik kesimpulan bahwa peningkatan daya saing industri kreatif sangat bergantung pada ketersedian modal, pembinaan kreatifitas pelaku usaha, serta aspek pemasaran yang terintegrasi teknologi. Perlu optimalisasi komponen pendukung industri kreatif model Porter Diamond agar daya saing industri kreatif Indonesia semakin meningkat di tengah pasar industri dunia.
\end{abstract}

Keywords: Ekonomi kreatif, Industri kreatif, Bekraf, UKM, Daya saing, Sentra Industri, Tamansari, Bogor, Porter Diamond, Klaster Strategi,

\section{Pendahuluan}

Usaha Mikro, Kecil, dan Menengah telah mampu membuktikan eksistensinya dalam perekonomian di Indonesia. Ketika krisis moneter melanda Indonesia di tahun 1998, banyak investor dan pengusaha besar yang mengalihkan modalnya ke negara-negara lain, sehingga perekonomian Indonesia dikala itu semakin terpuruk. Usaha kecil dan sektor riil mampu bertahan dan menopang roda perekonomian bangsa Indonesia.

Namun di sisi lain, UMKM juga menghadapi banyak permasalahan, yaitu terbatasnya modal kerja, Sumber Daya Manusia yang rendah, dan minimnya penguasaan ilmu pengetahuan serta teknologi (Sudaryanto dan Hanim, 2002). Kendala lain yang dihadapi IKM adalah keterkaitan dengan prospek usaha yang kurang jelas serta perencanaan, visi dan misi yang belum mantap. 
Hal ini terjadi karena umumnya IKM bersifat income gathering yaitu menaikkan pendapatan, dengan ciri-ciri sebagai berikut: merupakan usaha milik keluarga, menggunakan teknologi yang masih relatif sederhana, kurang memiliki akses permodalan (bankable), dan tidak ada pemisahan modal usaha dengan kebutuhan pribadi, hal tersebut yang merupakan salah satu penghambat IKM dalam persaingannya menghadapi produk-produk impor.

\begin{tabular}{|c|c|c|c|c|c|}
\hline Sektor/KBL 2009-2 Digit & 2011 & 2012 & 2013 & 2014 & (Triwulan III) \\
\hline 10 Makanan & 105.39 & 109.52 & 128.77 & 138.62 & 146.75 \\
\hline 11 Minuman & 99.45 & 100.44 & 112.28 & 117.56 & 133.09 \\
\hline 12 Pengolahan Tembakau & 98.14 & 99.31 & 95.05 & 58.87 & 89.64 \\
\hline 13 Tekstil & 103.95 & 107.02 & 115.79 & 120.88 & 127.4 \\
\hline 14 Pakaian Jadi & 105.61 & 110 & 119.37 & 124.14 & 131.17 \\
\hline 15 Kulit, Barang dari Kulit dan Alas Kaki & 104.5 & 113.79 & 124.4 & 128.72 & 133.85 \\
\hline $\begin{array}{l}16 \text { Kayu, Gabus (Tidak Termasuk Furnitur) dan } \\
\text { Anyaman dari Bambu, Rotan dsj }\end{array}$ & 100.88 & 101.52 & 104.75 & 103.43 & 96.05 \\
\hline 17 Kertas dan Barang dari Kertas & 100.19 & 106.31 & 108.3 & 112.59 & 127.35 \\
\hline 18 Pencetakan dan Reproduksi Media Rekaman & 103.63 & 109.91 & 112.21 & 125.01 & 136.85 \\
\hline $\begin{array}{l}19 \text { Produk dari Batu Bara dan Pengilangan } \\
\text { Minyak Bumi }\end{array}$ & - & & - & - & - \\
\hline 20 Bahan Kimia dan Barang dari Bahan Kimia & 100.55 & 102.12 & 109.08 & 107.4 & 127.29 \\
\hline
\end{tabular}

\section{Gambar 1. Indeks Produksi Tahunan Industri Mikro dan Kecil Indonesia Menurut 2- digit KBLI \\ Sumber: BPS, 2016}

Indeks produksi industri mikro dan kecil pada tahun 2011 sampai 2015 terus mengalami peningkatan. Pada tahun 2011 indeks produksi industri sebesar 104.71, pada tahun 2012 sebesar 111.88, pada tahun 2013 sebesar 117.15, pada tahun 2014 sebesar 122.91, dan pada tahun 2015 (triwulan III) sebesar 130.22. Pertumbuhan produksi industri mikro dan kecil dari tahun 2011 hingga tahun 2015 mengalami peningkatan dan penurunan di mana pada tahun 2012 sebesar 4.06, pada tahun 2013 sebesar 7.51, pada tahun 2014 sebesar 4.91, pada tahun 2015 (hingga triwulan III) sebesar 5.69.

Industri alas kaki merupakan salah satu industri non-migas yang diunggulkan oleh Indonesia, karena dapat memenuhi kebutuhan sandang individu, menyerap tenaga kerja yang banyak, serta menyumbang devisa ekspor non-migas yang cukup signifikan bagi negara. Seperti yang dapat dilihat pada Tabel 1 bahwa Industri alas kaki berskala mikro dan kecil memiliki indeks produksi yang tinggi setiap tahunnya selain insutri makanan. 


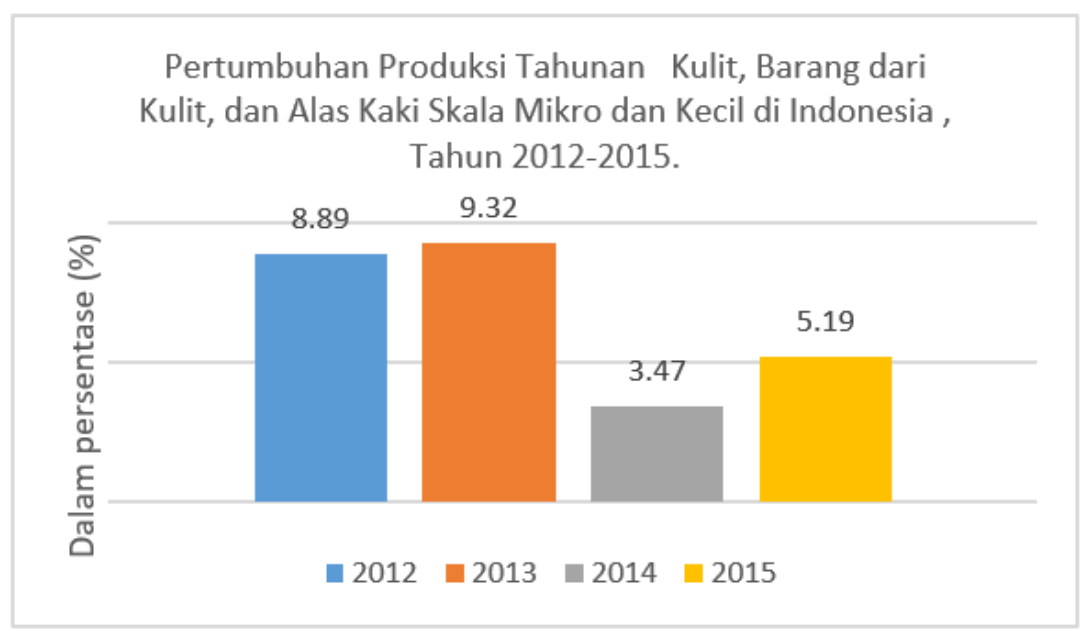

\section{Gambar 2. Pertumbuhan Produksi Industri Kulit, Barang dari kulit, dan Alas Kaki Indonesia \\ Sumber: BPS, 2015 (Diolah)}

Berdasarkan data yang diperoleh dari BPS bahwa pertumbuhan produksi Industri alas kaki berskala mikro dan kecil di Indonesia terus mengalami peningkatan, seperti yang dapat dilihat pada Gambar 1 bahwa pertumbuhan produksi di tahun 2012 sebesar 8,89\%, pada tahun 2013 9,32\%, tahun 2014 pertumbuhannya tidak setinggi pada tahun 2012 dan 2013 lalu yaitu sebesar $3,47 \%$, dan pada tahun 2015 pertumbuhannya meningkat kembali menjadi 5,19\%.

Daerah yang memiliki potensi yang besar dalam pengembangan sentra produksi alas kaki di Indonesia adalah Kabupaten Bogor, dimana untuk sentra produksi sepatunya terkonsentrasi di 3 wilayah yaitu Kecamatan Ciomas, Kecamatan Tamansari, dan Dramaga. Apabila dilihat dari jumlah unit usaha dan penyerapan tenaga kerjanya, Kabupaten Bogor merupakan sentra alas kaki terbesar kedua di Indonesia setalah Sentra Sepatu Cibaduyut, Bandung.

Kabupaten Bogor memiliki jumlah unit usaha kecil sepatu sebanyak 360 dengan penyerapan tenaga kerja sebanyak 1936 orang sedangkan Kota Bandung memiliki 646 unit usaha kecil sepatu dengan penyerapan tenaga kerja sebanyak 2788 orang. Di antara ketiga wilayah tersebut saat ini yang memiliki jumlah Industri Kecil alas kaki terbanyak adalah Kecamatan Tamansari. Berdasarkan hasil observasi diperkirakan $80 \%$ dari total rumah tangga di daerah tersebut menjalankan aktivitasnya di bidang Industri alas kaki.

Penelitian ini bertujuan untuk menganalisis potensi daya saing industri alas kaki di Kecamatan Tamansari serta merumuskan alternative strategi untuk meningkatkan daya saing tersebut. Penelitian ini diharapkan mampu memberi solusi bagi pelaku industri alas kaki kulit di Kecamatan Tamansari untuk meningkatkan upaya bisnis mereka menjadi lebih baik.

\section{Metodologi Penelitian}

Metode yang digunakan dalam penelitian ini adalah metode penelitian deskriptif dengan pendekatan kualitatif. Menurut Poerwandari (1998) penelitian kualitatif adalah penelitian yang menghasilkan dan mengolah data yang sifatnya deskriptif, seperti transkripsi wawancara, catatan lapangan, gambar, foto, rekaman dan lain-lain. Format desain penelitian kualitatif terdiri dari tiga model, yaitu format deskriptif, format verifikasi, dan format grounded research. 
Dalam penelitian ini digunakan metode kualitatif dengan desain deskriptif, yaitu penelitian yang memberi gambaran secara cermat mengenai individu atau kelompok tertentu tentang keadaan dan gejala yang terjadi (Koentjaraningrat, 1993). Peneliti akan memberikan gambaran dengan secara cermat tentang fenomena yang terjadi mengenai faktor-faktor yang dapat menghambat dan mempengaruhi perkembangan Industri kecil Alas kaki di Kecamatan Tamansari.

Selanjutnya penelitian kualitatif menurut Moleong (2007) adalah penelitian yang bermaksud untuk memahami fenomena tentang apa yang dialami oleh subjek penelitian misalnya perilaku, persepsi, motivasi, tindakan, dll, secara holistik, dan dengan cara deskripsi dalam bentuk katakata dan bahasa, pada suatu konteks khusus yang alamiah dan dengan memanfaatkan berbagai metode alamiah.

Menurut Bogdan dan Taylor (1975) yang dikutip oleh Moleong (2007) mengemukakan bahwa metodologi kualitatif sebagai prosedur penelitian yang menghasilkan data deskriptif berupa kata-kata tertulis atau lisan dari orang-orang dan perilaku yang dapat diamati. Selanjutnya dijelaskan oleh David Williams (1995) seperti yang dikutip Moleong (2007) mengemukakan bahwa penelitian kualitatif adalah pengumpulan data pada suatu latar alamiah, dengan menggunakan metode alamiah, dan dilakukan oleh orang atau peneliti yang tertarik secara alamiah.

Peneliti melakukan observasi di lingkungan industri kecil Alas Kaki Kecamatan Tamansari, Kabupaten Bogor selama dua bulan lebih. Dimulai dari tanggal 22 Febuari 2016 sampai tanggal 15 Mei 2016. Dengan metode observasi partisipatif yang dilakukan, peneliti dapat melihat dan merasakan secara langsung objek yang di teliti, hingga peneliti dapat mengetahui secara langsung objek yang diteliti.

Guna mendukung penelitian ini, peneliti juga mewawancarai beberapa informan yang menjadi narasumber. Berikut adalah daftar informan:

\section{Tabel 1. Daftar Informan}

\begin{tabular}{|c|l|c|c|c|c|}
\hline No. & \multicolumn{1}{|c|}{ Nama } & Inisial & Usia & Jenis Kelamin & Jabatan \\
\hline 1 & Endang & EN & 55 Tahun & Laki-Laki & Pemilik \\
\hline 2 & Rohmat & RO & 60 Tahun & Laki-Laki & Pemilik \\
\hline 3 & Aya & AY & 48 Tahun & Laki-Laki & Pemilik \\
\hline 4 & Dedi & DD & 52 Tahun & Laki-Laki & Pemilik \\
\hline 5 & Juhdi & JD & 48 Tahun & Laki-Laki & Pemilik \\
\hline 6 & Ujang Subel & UL & 42 Tahun & Laki-Laki & Pemilik \\
\hline 7 & Usman & UN & 40 Tahun & Laki-Laki & Pemilik \\
\hline 8 & Ujang Sobari & US & 53 Tahun & Laki-Laki & Pemilik \\
\hline
\end{tabular}

Data yang diperoleh dari wawancara, observasi, FGD, dan studi literature dikumpulkan ke dalam transkrip wawancara, notulen diskusi, dan catatan observasi. Seluruh data tertulis tersebut didokumentasikan dengan proses coding yang baik untuk dikelompokkan dalam kategori tertentu. Kategori isasi ini berguna untuk memformulasikan jawaban sebagai bahan analisis hasil penelitian. 
Data yang sudah melalui coding dan kategoriasi tersebut diuji dengan metode triangulasi. Proses ini untuk memastikan bahwa data yang diambil merupakan data yang valid dan kebenarannya bisa dipertanggungjawabkan. Selain itu, proses triangulasi juga dilakukan untuk tahap data cleaning untuk memastikan bahwa data yang dihasilkan merupakan data yang sudah teruji validity dan reliability-nya.

\section{Daya Saing}

\section{Landasan Berpikir dan Kajian Teori}

Daya saing menurut Michael Porter (1990) adalah produktivitas yang didefinisikan sebagai output yang dihasilkan oleh tenaga kerja. Secara umum maka pengertian daya saing adalah kemampuan perusahaan, daerah, negara, atau antar daerah untuk meningkatkan pendapatan dengan memanfaatkan tenaga keja dan sumberdaya lainnya yang produktif dan berkesinambungan untuk menghadapi persaingan dengan memaksimalkan potensi produk unggulannya. Oleh karena itu dalam konteks kabupaten/kota sebagai sebuah organisasi, daya saing diartikan sebagai kemampuan kabupaten/kota untuk mengembangkan kemampuan ekonomi-sosial wilayahnya guna meningkatkan kesejahteraan masyarakat di wilayahnya.

Menurut Michael Porter (1990), pada dasarnya ada 4 (empat) faktor yang mempengaruhi daya saing suatu negara, yaitu:

1. Strategi, Struktur, dan Tingkat Persaingan Perusahaan. Bagaimana unit-unit usaha di dalam suatu negara terbentuk, diorganisasikan, dan dikelola, serta bagaimana tingkat persaingan dalam negerinya.

2. Faktor Kondisi. Bagaimana ketersediaan sumber daya di suatu negara, yakni sumber daya manusia, bahan baku, pengetahuan, modal, dan infrastruktur. Ketersediaan tersebut menjadi penentu perkembangan industry di suatu negara. Ketika terjadi kelangkaan pada salah satu jenis faktor tersebut maka investasi industri di suatu negara menjadi investasi yang mahal.

3. Permintaan. Bagaimana permintaan di dalam negeri terhadap produk atau layanan industri di negara tersebut. Permintaan hasil industri, terutama permintaan dalam negeri, merupakan aspek yang mempengaruhi arah pengembangan faktor awalan keunggulan kompetitif sektor industri. Inovasi dan kemajuan teknologi dapat terinspirasi oleh kebutuhan dan keinginan konsumen.

4. Keberadaan Terkait dan Pendukung. Keberadaan industri pemasok atau industri pendukung yang mampu bersaing secara internasional. Faktor ini menggambarkan hubungan dan dukungan antar industri, dimana ketika suatu perusahaan memiliki keunggulan kompetitif, maka industry-industri pendukungnya juga akan memiliki keunggulan kompetitif. 


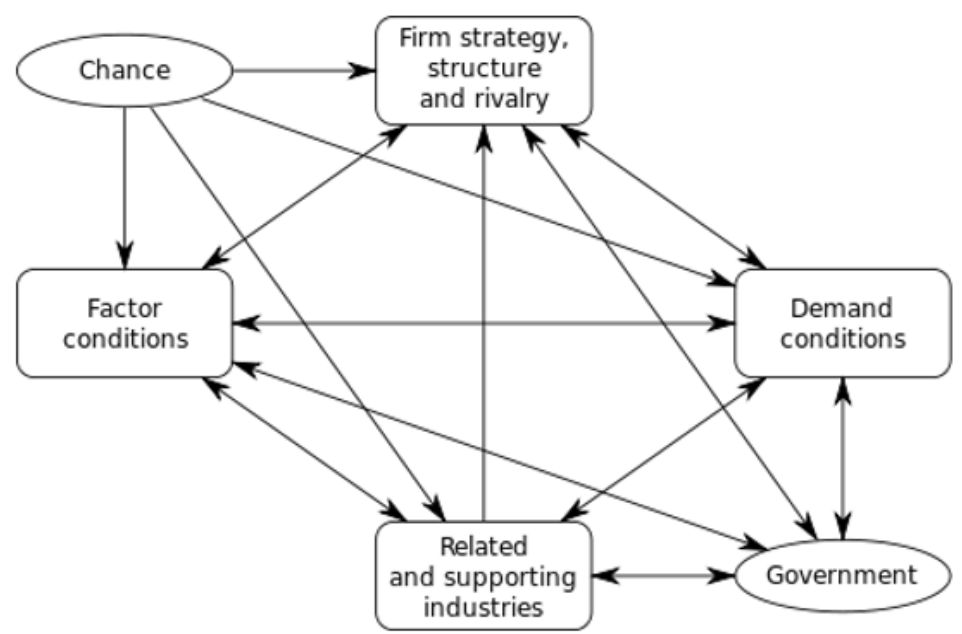

Gambar 3. Model Diamond Porter

Keempat komponen yang disebut sebagai model Porter's Diamond tersebut mengkondisikan lingkungan di mana perusahaan-perusahaan berkompetisi dan mempengaruhi keunggulan daya saing suatu bangsa. Analisis tersebut menyatakan bahwa pemerintahan suatu negara memiliki peran penting dalam membentuk ekstensifikasi faktor-faktor yang menentukan tingkat keunggulan kompetitif industri suatu negara. Hal ini diperjelas dengan adanya 2 (dua) variabel tambahan yang mempengaruhi daya saing seperi yang dapat dilihat pada gambar 2.1, yaitu:

1. Peluang. Perkembangan yang berada di luar kendali perusahaan-perusahaan (dan biasanya juga di luar kendali pemerintah suatu bangsa), seperti misalnya penemuan baru, terobosan teknologi dasar, perkembangan politik eksternal, dan perubahan besar dalam permintaan pasar asing.

2. Pemerintah. Pemerintah pada semua tingkatan pemerintahan dapat meningkatkan atau memperlemah keunggulan nasional. Peran pemerintah terutama dalam membentuk kebijakan yang mempengaruhi komponen-komponen dalam Diamond Porter. Misalnya, kebijakan anti-trust mempengaruhi persaingan nasional. Regulasi dapat mengubah faktor permintaan (misalnya regulasi terkait subsidi BBM). Kebijakan pemerintah yang mendukung pendidikan dapat mengubah kondisi faktor produksi. Belanja pemerintah dapat merangsang industri terkait dan pendukung.

Selain Model Porter's Diamond di atas, adapun teori persaingan yang dikemukakan oleh Michael Porter yang dapat digunakan untuk menganalisis persaingan, bagaimana lingkungan yang kompetitif akan berpengaruh terhadap pemasaran suatu produk yaitu teori "Porter's Five Forces Model". Porter menilai bahwa perusahaan secara nyata tidak hanya bersaing dengan perusahaan yang ada dalam industri saat ini.

Model ini dapat menggambarkan situasi bisnis yang sedang dijalankan, dan juga dapat membantu dalam mengetahui keunggulan posisi kompetisi saat ini dan yang akan dihadapi kemudian. Sehingga perusahaan dapat meningkatkan kekuatan, mengantisipasi kelemahan dan menghindari perusahaan dalam mengambil keputusan yang salah. 


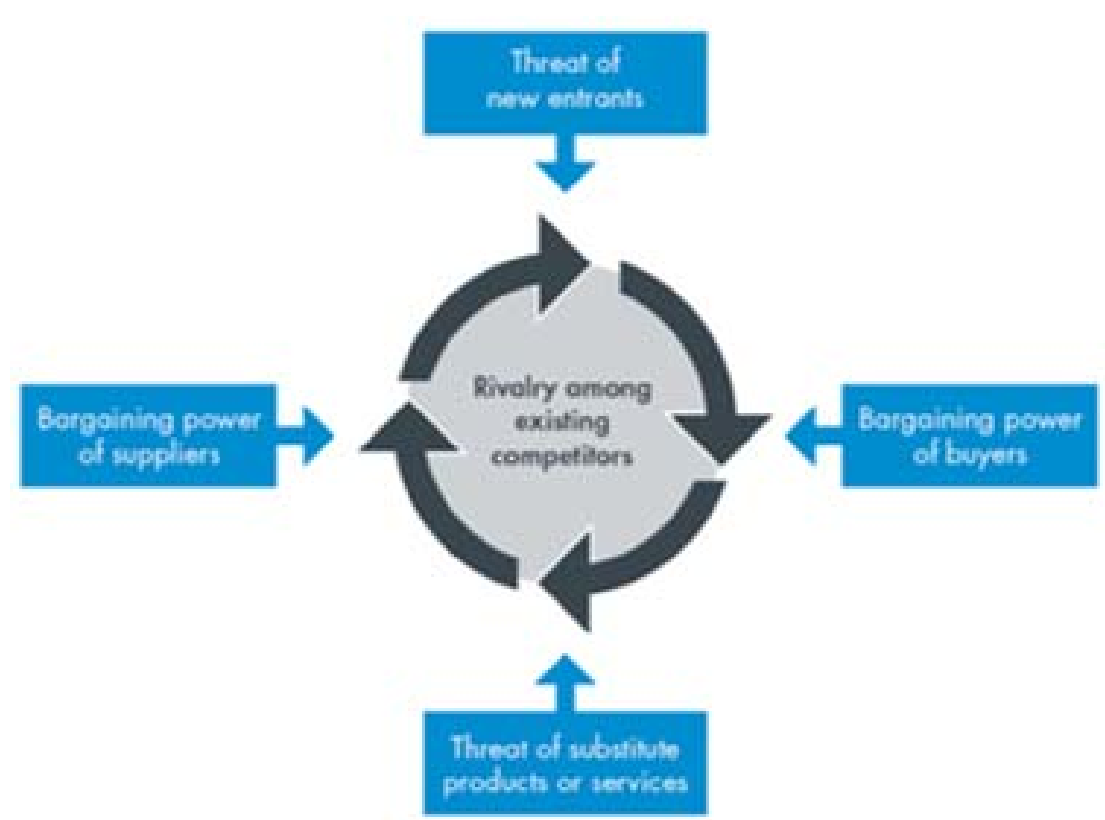

Gambar 4. Porter's Five Forces Model

Dalam model Porter's Five Forces terdapat lima kekuatan bersaing seperti yang ditunjukkan pada Gambar 2.3, yaitu:

a. Masuknya pesaing baru (Threat of New Entrants)

b. Ancaman dari produk pengganti (substitusi)

c. Kekuatan penawaran pembeli

d. Kekuatan penawaran pemasok

e. Persaingan diantara perusahaan yang ada

\section{Analisis SWOT}

Analisis SWOT adalah identifikasi berbagai faktor secara sistematis untuk merumuskan strategi perusahaan. Analisis ini didasarkan pada logika yang dapat memaksimalkan kekuatan (Strenghts) dan peluang (Oppurtunities), namun secara bersamaan dapat meminimalkan kelemahan (Weaknesess) dan ancaman (Threats). Proses pengambilan keputusan strategis selalu berkaitan dengan pengembangan misi, tujuan, strategi, dan kebijakan perusahaan. Dengan demikian perencanaan strategis perusahaan (kekuatan, kelemahan, peluang, dan ancaman) dalam kondisi yang ada saat ini. Hal ini disebut analisis situasi yaitu model yang paling popular untuk analisis situasi adalah Analisis SWOT.

Penelitian menunjukkan bahwa kinerja perusahaan dapat ditentukan oleh faktor internal dan eksternal. Kedua faktor tersebut harus dipertimbangkan dalam analisis SWOT. SWOT adalah singkatan dari lingkungan Internal Strengths dan Weaknesses serta lingkungan External Opportunities dan Threats yang dihadapi dunia bisnis. Analisis SWOT membandingkan antara faktor eksternal peluang (Opportunities) dan ancaman (Threats) dengan faktor internal kekuatan (Strengths) dan kelemahan (Weakness). 
Analisis SWOT terdiri dari empat faktor, yaitu:

a. Strengths (kekuatan)

Kekuatan adalah keuntungan relatif yang dipunyai oleh perusahaan dibandingkan dengan pesaing dari perusahaan. Kompetensi yang dimiliki oleh perusahaan yang membedakan dari pesaing lainnya akan menjadi keuntungan komparatif dalam pemasaran produk atau jasa perusahaan. Kekuatan bersumber dari sumberdaya dan kompetensi yang dimiliki oleh perusahaan.

b. Weakness (kelemahan)

Kelemahan adalah keterbatasan atau tidak efisiennya salah satu sumber daya yang dimiliki perusahaan. Hal ini juga dapat diartikan sebagai kompetensi yang dimiliki oleh perusahaan hamper sama dengan pesaing lainnya yang akan mengurangi efektifitas perusahaan dalam menghasilkan produk atau jasa.

c. Opportunities (peluang)

Peluang atau kesempatan adalah keuntungan yang dimiliki oleh perusahaan dalam suatu situasi di lingkungan eksternal perusahaan. Perubahan dalam hal segmentasi, teknologi, peraturan, hubungan dengan pemasok yang telah diantisipasi merupakan peluang atau kesempatan perusahaan.

d. Threats (ancaman)

Ancaman adalah suatu kondisi yang merugikan perusahaan yang meliputi: masuknya pesaing, teknologi baru, pertumbuhan negative, perubahan peraturan dan lain-lain. Ancaman dapat merupakan hambatan bagi perusahaan baik masa sekarang maupun masa yang akan mendatang.

\section{TOWS Matrix}

TOWS matrix adalah sebuah alat yang dapat digunakan untuk menciptakan faktor strategis perusahaan. Bagaimana peluang dan ancaman dihadapi oleh perusahaan dapat disesuaikan dengan kekuatan dan kelemahan yang dimiliki oleh perusahaan tersebut. TOWS matrix akan memberikan empat set dari strategi alternative bagi perusahaan.

Tabel 2. TOWS Matrix

\begin{tabular}{|c|c|c|}
\hline Faktor Strategis & STRENGTHS $(S)$ & WEAKNESS $(W)$ \\
\hline OPPORTUNITIES $(O)$ & Strategi SO & Strategi WO \\
\hline THREATS $(T)$ & Strategi ST & Strategi WT \\
\hline
\end{tabular}

\section{a. Strategy SO (Strength - Opportunities)}

Strategi ini diformulasikan berdasarkan perilaku perusahaan, yang didesain dengan menggunakan kekuatan perusahaan untuk memperoleh kesempatan yang tercipta dari keadaan lingkungan.

b. Strategy WO (Weakness - Opportunities)

Strategi ini diformulasikan dengan menggunakan kesempatan yang disediakan oleh lingkungan agar kelemahan perusahaan dapat diminimalisir sekecil mungkin.

c. Strategy ST (Strength - Threat)

Strategi ini diformulasikan dengan menggunakan kekuatan perusahaan untuk mengatasi ancaman akibat dari lingkungan sekitar.

d. Strategy WT (Weakness - Threat)

Strategi ini diformulasikan untuk menghadapi dan mengurangi dampak dari ancaman serta mengurangi resiko kerusakan dari kelemahan. 


\section{Karakteristik Industri dan Pelaku Industri}

\section{Pembahasan}

Karakeristik pendidikan pemilik Industri kecil Alas kaki di Tamansari bervariasi antara SD sampai S1. Mayoritas usaha mereka merupakan usaha warisan, sehingga dilihat dari lama usahanya mayoritas berkisar 5-10 tahun (40\%) dan 60\% sudah di atas 10 tahun. Jumlah tenaga kerja yang dimiliki Industri kecil pada umumnya bervariasi dimana 20\% memiliki jumlah tenaga kerja antara 6-12 orang sedangkan $80 \%$ memiliki tenaga kerja di bawah 5 orang. Adanya kendala dalam permodalan menyebabkan adanya kerjasama dengan pengumpul dalam hal pengadaan bahan baku dan pemasaran produk. Bentuk usaha Industri kecil Alas Kaki pengrajin adalah $100 \%$ berbentuk bengkel. Industri Kecil Mandiri belum memiliki struktur organisasi yang jelas, sehingga tenaga kerjanya hanya terdiri dari pemilik dan pekerja. Tenaga kerja Industri kecil Alas Kaki di Tamansari, pada umumnya merupakan tenaga kerja harian ataupun borongan. Sedangkan untuk pola kemitraan, semuanya (100\%) belum menjalin kemitraan dengan instansi ataupun lembaga manapun.

Bahan baku yang digunakan pada proses produksi sepatu, yaitu sol, imitasi atau sintetis, lem dan asesoris. Semua bahan baku untuk kulit sepatu yang diproduksi, 100\% merupakan bahan sintetis, agar harganya relatif murah. Dalam mendapatkan bahan baku tidak mendapatkan kendala, tetapi fluktuasi harga bahan baku merupakan kendala eksternal yang dihadapi oleh pemilik industri sepatu. Harga bahan baku yang tidak stabil mempengaruhi produksi dan tingkat keuntungan yang didapatkan. Cara mendapatkan bahan baku dengan perjanjian dibayar kemudian dengan tenggang waktu tertentu (Bon Putih). Pada proses produksi sepatu, alat yang digunakan adalah mesin jahit, mesin press dan mesin seset, bahkan ada yang sudah menggunakan mesin embos atau merk.

Berdasarkan hasil wawancara didapatkan bahwa seluruh informan yang terdiri dari 8 orang pemilik usaha Alas Kaki, konsumennya merupakan atau memiliki toko grosir sepatu dan sandal yang berbentuk fisik maupun secara online. Hal tersebut mengindikasikan bahwa tidak ada konsumen yang bersifat end user, karena terdapat jumlah minimal dalam melakukan pemesanan yaitu sebanyak 1 kodi (20 Pasang). Lokasi konsumen tersebut beragam ada yang berasal dari Kota Bogor (Pasar Anyar, Mall BTM), luar kota seperti Jakarta (Jatinegara, Tanah Abang, Mangga Dua), Palembang, Padang, Makassar, Lampung, hingga Papua.

\section{Analisis SWOT dan TOWS Matriks}

Analisis SWOT dilakukan untuk mengidentifikasi berbagai faktor secara sistematis yang dapat digunakan untuk merumuskan strategi perusahaan atau industri kecil. Analisis ini didasarkan pada logika yang dapat memaksimalkan kekuatan (Strenghts) dan peluang (Oppurtunities), namun secara bersamaan dapat meminimalkan kelemahan (Weaknesess) dan ancaman (Threats). Dengan demikian perencanaan strategis industry kecil (kekuatan, kelemahan, peluang, dan ancaman) dalam kondisi yang ada saat ini. 


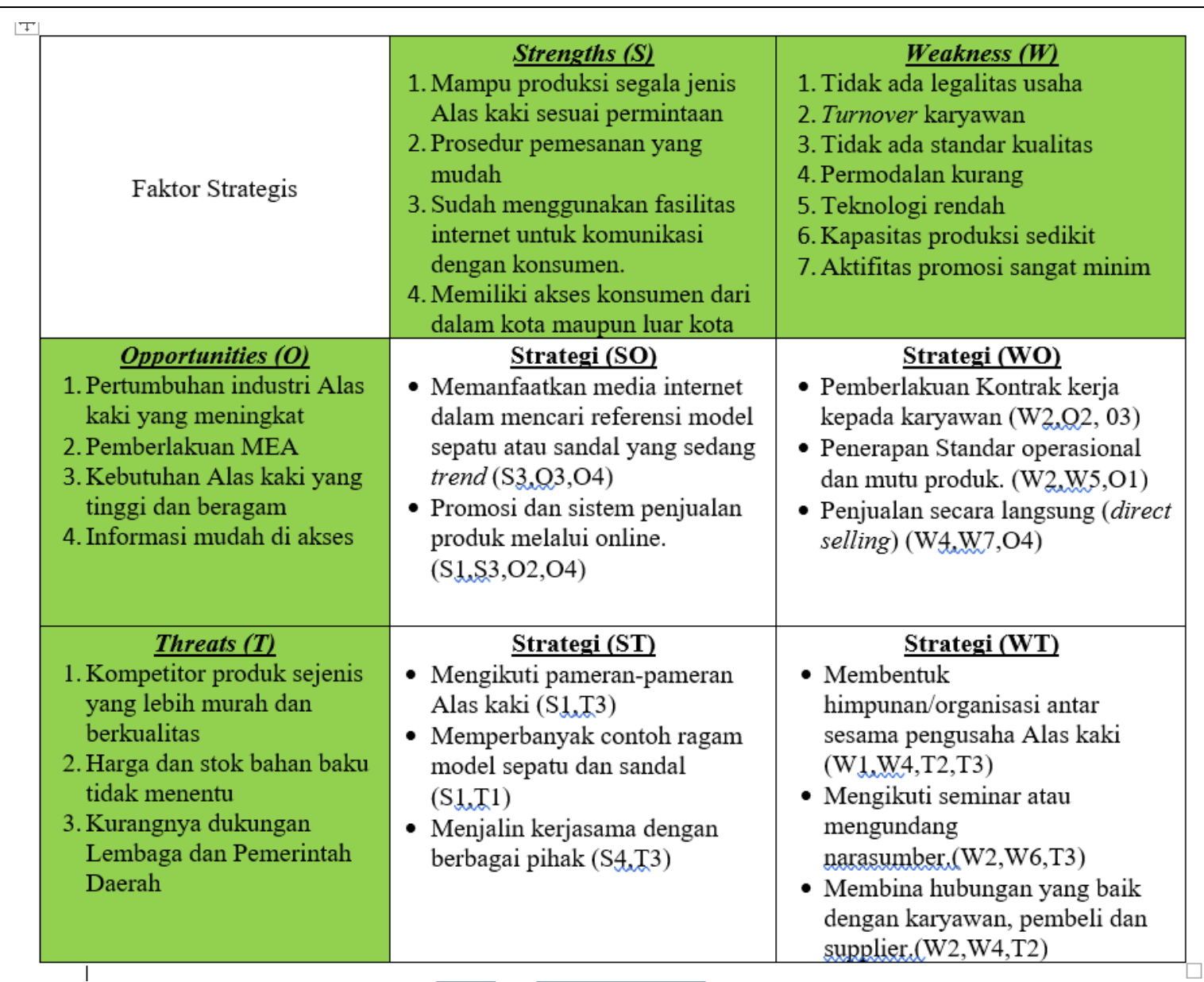

\section{Gambar 5. Analisis SWOT}

Rumusan strategi yang diperoleh dari analisis SWOT diatas merupakan rumusan strategi yang bertujuan untuk memanfaatkan kekuatan dan peluang serta meminimalkan kelemahan dan ancaman, dimana dalam implementasinya harus melibatkan masyarakat, pelaku usaha, pemerintah dan pihak-pihak terkait lainnya. Dengan strategi tersebut, diharapkan pemerintah dan pelaku usaha memiliki kewenangan masing-masing dalam pengembangan kawasan industry kecil Alas Kaki di Kecamatan Tamansari.

\section{Strategi S-O}

a. Memanfaatkan media internet dalam mencari referensi serta informasi mengenai model sepatu atau sandal yang sedang trend di masyarakat. Hal tersebut juga dapat dijadikan sebagai bahan referensi dan pertimbangan untuk pembeli agar penjualan mereka juga meningkat.

b. Memasarkan produk hasil karyanya dan juga dapat melakukan pemesanan melalui media internet atau social media yang bebas biaya seperti twitter, Instagram, BBM.

\section{Strategi S-T}

a. Mengikuti dan berpartisipasi dalam pameran-pameran Alas kaki, pameran kreativitas bahan kulit atau kanvas.

b. Mengumpulkan dan memperbanyak sampel sepatu dan sandal. Dapat juga membuat katalog gambar yang berisi koleksi-koleksi model sepatu dan sandal.

c. Mejalin kerjasama dengan beberapa pihak yang terkait. 
3. Strategi W-O

a. Pemberlakuan kontrak atau perjanjian kerja kepada karyawan untuk mengurangi resiko turnover, yang dapat menghambat proses produksi.

b. Penetapan SOP dalam penggunaan alat serta pemakaian bahan baku untuk mengejar efisiensi material. Setelah itu dilakukannya proses Quality control untuk menjaga kerapihan dan kualitas produk.

c. Melakukan penjualan secara langsung (direct selling).

\section{Strategi W-T}

a. Membentuk himpunan atau organisasi mandiri antar sesame pengusaha Alas kaki. Pembentukan organisasi sangat bermanfaat dalam mencari solusi dari suatu masalah secara musyawarah, sebagai wadah untuk saling sharing mengenai kendala, peluang, maupun target yang ingin dicapai.

b. Mengikuti seminar atau mengundang narasumber mengenai manajemen produksi, efektifitas kinerja, efisiensi biaya produksi, atau pemanfaatan sumberdayasumberdaya lainnya.

c. Membina hubungan yang baik dengan seluruh stakeholder, yang terdiri dari konsumen, karyawan, serta supplier bahan baku.

\section{Kesimpulan}

Setelah melakukan analisis, maka peneliti berkesimpulan bahwa upaya untuk meningkatkan daya saing kluster industri alas kaki di Kecamatan Tamansari bisa dilakukan dengan beberapa prioritas strategi berikut ini:

\section{Promosi dan sistem penjualan produk melalui online.}

Hal ini dilakukan dikarenakan industri kecil Alas kaki Tamansari memiliki kemampuan dalam memproduksi segala jenis alas kaki dengan model yang beragam dan prosedur pemesanan yang mudah, dengan adanya peluang yang luas dalam pemanfaatan media online yang bebas biaya maka akan sangat membantu dalam proses penjualannya. Karena berdasarkan riset yang dilakukan oleh BPS (2014), pengguna internet di Indonesia sebanyak 77,81\% memanfaatkan internet untuk mencari informasi mengenai barang dan jasa yang mereka butuhkan. Dan berdasarkan riset yang dilakukan oleh Asosiasi E-commerce Indonesia (idEA) pada Januari 2014, produk yang paling banyak dibeli secara online adalah produk fashion sebesar $78 \%$, yang di dalamnya terdapat kategori produk Alas Kaki. Strategi ini diperoleh dari kekuatan (S1 dan S3), dan peluang (02 dan 04).

\section{Penerapan Standar operasional dan mutu produk.}

Dikarenakan kelemahan dari pelaku industri Alas kaki di Kecamatan Tamansari adalah tidak adanya standar mutu dari produk, maka sangat diperlukan adanya penerapan standar operasional prosedur dalam pemanfaatan alat-alat maupun bahan baku, serta penerapan quality control dari setiap produk yang dihasilkan agar kualitas dari produk tersebut memiliki standar kualitas pengerjaan yang baik. Tentu tujuan dari penerapan strategi ini adalah mengurangi tingkat kecacatan produk dan tingkat pengembalian barang yang akan merugikan pihak pengrajin. Strategi ini diperoleh dari kelemahan (W2 dan W5), dan peluang (01).

Membina hubungan yang baik dengan karyawan, pembeli dan supplier.

Aspek penting dalam kegiatan produksi di industry kecil Alas kaki ini adalah aspek tenaga kerja dan aspek bahan baku. Hubungan kerja yang baik antara tenaga kerja diperlukan agar karyawan tersebut dapat bekerja secara maksimal dalam proses produksi. Serta dikarenakan saat ini 
terdapat kendala kelangkaan tenaga kerja, maka sebisa mungkin karyawan yang sudah ada itu dipertahankan sehingga proses produksi tersebut tetap berjalan sesuai dengan rencana dan optimal.

Selain itu pembinaan hubungan yang baik dengan pihak supplier dibutuhkan untuk tetap mendapatkan informasi terkait ketersediaan dan harga bahan baku. Karena pada saat peak season seperti menjelang lebaran dan natal kerap terjadi kelangkaan bahan baku dan kenaikan harga, dengan adanya hubungan yang baik dengan toko bahan baku maka pihak produsen diharapkan dapat melakukan antisipasi dengan cara pemesanan bahan baku jauh hari sebelum proses produksi itu dilakukan, guna menghindari adanya kendala sulit mendapatkan bahan baku. Strategi ini diperoleh dari kelemahan (W2 dan W4), dan ancaman (T2).

\section{Mengikuti pameran-pameran Alas kaki}

Keikutsertaan dalam pameran-pameran dapat meningkatkan awareness dari produk yang dihasilkan dan kawasan sentra produsen Alas Kaki Tamansari, mendapatkan ide maupun informasi produk yang berpotensi tinggi di pasar, serta juga dapat membuka jalur kerjasama yang baru dan lebih luas dengan para konsumen ataupun supplier. Diharapkan dengan keikutsertaan tersebut maka pihak pemerintah terutama pemerintah daerah terpicu untuk membantu mengembangkan kawasan sentra Alas Kaki Kecamatan Tmaansari yang produktif dan memiliki potensi yang bagus tersebut.

Atas pertimbangan yang telah peneliti deskripsikan, keempat strategi diatas yang menurut peneliti jadikan sebagai prioritas strategi beserta implementasinya. Namun dikarenakan penelitian ini membahas mengenai strategi pengembangan wilayah dan tidak adanya batasan waktu tertentu, maka semua alternatif strategi yang disebutkan pada Matriks TOWS diatas dapat diimplementasikan semua oleh pembaca.

\section{Diskusi}

Penelitian ini merupakan upaya untuk menggambarkan daya saing industri kreatif Indonesia dengan mengangkat studi kasus pada industri alas kaki di Tamansari, Bogor. Penelitian tidak ditujukan untuk menggambarkan seluruh upaya peningkatan industri kreatif Indonesia, namun model analisis yang digunakan bisa diterapkan dalam menganalisis industri kreatif lainnya.

Perlu penelitian lebih lanjut mengenai keabsahan penggunaan model analisis ini. Diharapkan, model analisis untuk memetakan daya saing industri ini bisa menjadi sebuah panduan bagi para pelaku industri kreatif Indonesia untuk memetakan staretgi bisnis mereka sehingga mampu bersaing di pasar lokal, nasional, hingga global.

\section{Sumber Referensi}

Moloeng, Lexy J., “Metodologi Penelitian Kualitatif (edisi revisi), Bandung: PT. Remaja Rosda Karya, 2010.

Soegiono, Memahami Penelitian Kualitatif, Bandung: CV. Alfabeta., 2012

Sugiyono, 2006, Metode Penelitian Bisnis, Penerbit Alfabeta, Bandung

Porter, Michael E. Porter (1990). The Competitive Advantage of Nations. Free Press 
Allio, Robert J. (1990), "Flaws in Porter's Competitive Diamond?," Planning Review, 18 (No. 5, September/October), 28-32

Sudaryanto dan Hanim, Anifatul. 2002. Evaluasi kesiapan UKM Menyongsong Pasar Bebas Asean (AFTA) : Analisis Perspektif dan Tinjauan Teoritis. Jurnal Ekonomi Akuntansi dan Manajemen, Vol 1 No 2, Desember 2002

Rahmana, Arief. 2008. Usaha Kecil dan Menengah (UKM), Informasi Terdepan tentang Usaha Kecil Menengah, (online), (http://infoukm.wordpress.com)

David, Fred R., 2006, Strategic Management Concepts and Cases, Tenth edition, Pearson Prentice Hall Inc

Rangkuti, Freddy, 2000, Analisis SWOT Teknik Membedah Kasus Bisnis, PT Gramedia Pustaka Utama, Jakarta

Kementerian Perindustrian. 2012. Perkembangan Ekspor Indonesia Berdasarkan Sektor pada Tahun 2007-2011; Pemantauan Ekspor Kelompok Hasil Industri Alas Kaki tahun 20082011; Pemantauan Impor dan Ekspor Kulit, Barang Kulit, dan Sepatu/Alas Kaki Tahun 2009-2011

$\underline{\text { https://www.bps.go.id/Subjek/view/id/170 }}$

https://www.bps.go.id/Subjek/view/id/35

http://www.kemenperin.go.id/artikel/15761 Industri-Alas-Kaki-Agresif-Ekspansi-Bangun$\underline{\text { Pabrik }}$

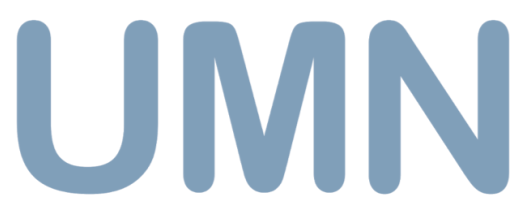

